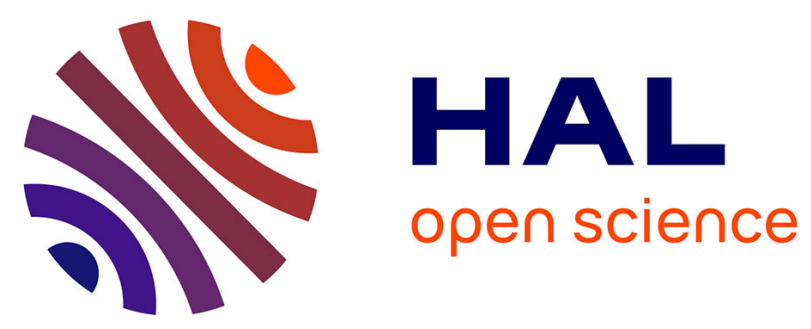

\title{
Monopsony Theory Revisited
}

Xavier Méra

\section{To cite this version:}

Xavier Méra. Monopsony Theory Revisited. Matthew McCaffrey. The Economic Theory of Costs: Foundations and New Directions, Routledge, 2017. halshs-01519191v2

\section{HAL Id: halshs-01519191 \\ https://shs.hal.science/halshs-01519191v2}

Submitted on 8 Jul 2017

HAL is a multi-disciplinary open access archive for the deposit and dissemination of scientific research documents, whether they are published or not. The documents may come from teaching and research institutions in France or abroad, or from public or private research centers.
L'archive ouverte pluridisciplinaire HAL, est destinée au dépôt et à la diffusion de documents scientifiques de niveau recherche, publiés ou non, émanant des établissements d'enseignement et de recherche français ou étrangers, des laboratoires publics ou privés. 


\title{
MONOPSONY THEORY REVISITED
}

\author{
XAVIER MÉRA
}

Xavier Méra holds a PhD in economics from the University of Angers, France. He is a teaching and research assistant at Université Rennes 2 and an associated scholar of the Ludwig von Mises Institute.

A version of this paper is forthcoming in The Economic Theory of Costs: Foundations and New Directions, edited by Matthew McCaffrey, Routledge 2017. The author wishes to thank Renaud Fillieule, Guido Hülsmann, Tudor Smirna and Georges Lane for their comments on an earlier version of the paper. The usual caveats apply.

\section{INTRODUCTION}

The core idea of monopsony theory is the possibility of "profits at the expense of wages" (Machlup 1952, p. 362) or, more generally, profits through an artificial lowering of money costs (expenses). It has long been a theoretical curiosity in the academic literature. Or so it was before the 1990s. To be sure, then as well as now, most microeconomics textbooks had some section dedicated to monopsony theory, showing how the price and the quantity sold of a good or service -usually labor services- are determined when there is only one buyer. But it was seen more as an interesting thought experiment, however impeccably carried out, than as an empirically relevant piece of theorizing (Friedman 1976, p. 193). The reason is that scholars had found difficult to come up with genuine instances of monopsonies in the real world.

The situation has changed in the past two decades as a new generation of scholars (Boal and Ransom 1997, Manning 2011) has enthusiastically rediscovered and built upon the original insights of Robinson (1933, pp. 211-305). The new creed is that mere "frictions" on the labor markets are considered sufficient for "monopsony power" to emerge. Since there is no need anymore for a sole buyer or even a few buyers ("oligopsony") for a monopsony price to emerge, the distorsions involved, compared to perfect competition, are now taken to be a problem of far higher empirical relevance than they were before.

Obviously monopsony theory has policy implications, such as helping make a case for minimum wage laws which are otherwise viewed by economists with utmost suspicion, as far as their efficacy 
in fulfilling the goal of raising wage rates without adverse effect on the labor force is concerned. Unsurprisingly then, the renewed legitimacy of monopsony theory in the academic field is spilling over to the field of policy-making, as no less than the White House Council of Economic Advisers has recently released an issue brief relying on the recent literature to promote various government interventions in labor markets (Irwin 2016, Council of Economic Advisers 2016). Last but not least, if proof was required that monopsony theorizing makes an impact outside the academic world, Blair and Harrison (2010, pp. xiii-14) have shown that antitrust court cases in the US have increasingly dealt with the behavior of buyers since the 1990s.

"The most important idea in the analysis of monopsonistic labor markets..." writes Manning (2003, p. 41), is that "...the labor supply to an individual firm is increasing in the wage paid so that the labor supply curve facing an individual firm is not infinitely elastic as is assumed in perfect competition". Reading the recent literature, one would not guess that the relevance of this dichotomy between monopsonistic and competitive markets has been challenged. In particular, longstanding criticisms of the underlying imperfect versus perfect competition framework from some "Austrian" scholars have generally been overlooked. Yet this is of tremendous importance: if the distinction is artificial, perfect competition cannot serve as a benchmark to contrast imperfect competition outcomes -including monopsony prices- with its own.

Although older Austrians such as Böhm-Bawerk (1962, pp. 162-67), and their fellow travelers ${ }^{1}$ had room in their price theory for monopsony prices, Mises (1949, pp. 380-81, 591-95) and Rothbard (1962, pp. 717-18) ended up almost scraping the whole idea as a consequence of rejecting the perfect vs imperfect competition paradigm. To them, monopsony theory essentially belonged to the analysis of socialism (with one and only one possible employer, the State), and even there the concept of a monopsony price did not make sense. This seems to be the view contemporary Austrians have adopted too (Bellante 2007, Block Barnett 2009).

However, I want to show here that Mises, Rothbard, and their followers, may have gone too far and that their predecessors were onto something. In other words, there was no need for the perfect vs imperfect competition framework to conceive of a theory of monopsony prices in a market economy, in the same way that they did not need it to endorse a theory of monopoly prices (Mises

1 See for example Wieser (1927, pp.218-20), Clark (1915, p. 76), and Davenport (1913, p. 481-82). 
1949, pp. 354-85; Rothbard 1962, pp. 903-07). Expanding on Méra (2010) which explored the relationship between monopoly prices for products and the prices of their factors of production, I want to show that the Austrian case against the imperfect vs perfect competition framework and Eugen von Böhm-Bawerk’s distinctively Austrian law of costs (Böhm-Bawerk 1930, pp. 223-34) provide the causal-realist foundations (Klein 2008) to revisit the issue and build what might be called a theory of "monopoly price-gap", with monopsony prices and monopoly prices arising together, out of the same pattern of production in a hampered market economy, and accounting for such a gap.

Section 2 is a brief overview of the classic and new monopsony literatures. Since the causal-realist case against their common framework remains largely overlooked and since it highlights some fundamental principles necessary to our more constructive task, section 3 restates it to show how both the classic and new theories are built on questionable grounds. Section 4 outlines what Mises and Rothbard had in store as an alternative to the dominant paradigm and how it lead them in particular to dismiss monopsony-related concerns. Section 5 questions part of their findings and lays out the foundations of the theory of monopoly price-gap, based on the idea that monopsony and monopoly -defined as grants of privilege in buying and selling (Rothbard 1962, pp. 665-71)- go hand in hand in the context of production decision making. Sections 6 and 7 lay out the theory, when the factors of production involved are specific to one production process and when they are not, respectively. The latter stresses in particular that non-specificity does not shield factor owners from downward pressure on their prices, as a consequence of the law of costs, despite mainstream and Austrian claims to the contrary. Finally the conclusion asks how this recasting of monopsony theory into a larger framework affects the question of its empirical relevance, i.e. the potential pervasiveness of monopoly-monopsony distorsions, and answers it in non-exhaustive fashion.

\section{Classic And New Monopsony THEORY}

It is common to distinguish between "classic" and "new" monopsony theory (Manning 2008). Classic monopsony is the typical textbook version. In short, one buyer faces many sellers, so that the quantity supplied to this "monopsonist" is an increasing function of price. This stands in contrast with the perfectly competitive case in which the supply schedule addressed to any buyer is perfectly elastic (the corresponding supply curve being perfectly flat) at the market equilibrium 
price, each buyer is one among many so that any attempt on his part to lower its price would result in the hiring of all units by its competitors at the ongoing price. In other words, the buyer is a "price-maker" in the first case and a "price-taker" in the second.

Since the model typically deals with the market for some factor of production -usually labor factors facing the demand of a profit-maximizing employer- the consequences are as follows. The employer will hire or buy units of the factor until the monetary value of the marginal product of the factor equals its marginal cost. In perfect competition, this means that each employer hires up to the point where the marginal revenue product equals the price of the factor. Under less than perfectly competitive conditions however, marginal cost is above the price of the factor for any quantity hired but the smallest, since the price rises for all units hired as the quantity of factors hired grows (unless one deals with the case of price discrimination). Therefore, the profit maximizing point will be reached with a lower amount of factors hired than would have occurred under perfect competition, and there will be a gap between the value of the marginal product and the price of the factor, the marginal revenue product being higher and the price of the factor being lower than they would be under perfect competition.

This gap is a measure of his "market power". Under this setting, a legally mandated minimum price above this monopsony price can conceivably improve the situation of all sellers of the factor, as well as improve efficiency in the resource allocation process, as long as it is not set above its market-clearing price. Indeed, if the minimum wage happened to be the exact market-clearing wage, the profit-maximizing quantity of labor hired would be the same than under perfect competition (which usually serves as the benchmark for welfare comparisons).

Classic monopsony also refers to oligopsony, when the market structure is such that a few buyers do compete. The theory becomes more complicated because one must take into account the strategic interactions between buyers, since the supply schedules facing each buyer is affected by their competitor's decisions. Nevertheless, the heart of the matter remains that the buyers we deal with face less than perfectly elastic supply schedules.

In the same way that "monopoly" now often refers to any situation in which a seller has some market power (faces a less than perfectly elastic demand schedule), "monopsony" nowadays often refers to any situation in which a buyer faces a less than perfectly elastic supply schedule (Manning 
2008), including monopsony in the narrow sense and oligopsony. The "new monopsony" literature still is about imperfect competition then, forward sloping supply curves, etc. The main difference is, as Manning (2008) puts it, that "modern theories of monopsony do not generally argue that employer market power over their workers derives from there being a small number of employers. They tend to emphasize the role of frictions in the labour market." It is not surprising then that these authors find more room for monopsonistic distorsions in the economy than their predecessors. For as long as workers do not immediately quit a firm en masse whenever the employer "cuts wages by one cent" (Manning 2008), which one can confidently assumes rarely happens, employers have some market power.

Manning (2003, p. 3) merely follows coherently this thread of thought when he asserts that the simple monopsony model is a better approximation of the situation for any firm than the perfectly competitive model. However, he is a leading author in developing a more sophisticated approach, drawing on the "search costs" literature in particular (Manning 2006), pursuing Burdett and Mortensen's (1998) initial line of thought. In a nutshell, the idea is that looking for a job is a costly endeavor, so that workers do not automatically find it beneficial to switch jobs when a better-paying alternative is available. This leaves room for monopsonistic behavior on the part of employers. As Borjas (2013, p. 192) summarizes it: "In effect, mobility costs help generate an upward-sloping supply curve for a firm.”

A large part of the new monopsony literature is then dedicated to estimating the elasticity of supply of various groups of laborers and the extent to which employers actually take advantage of their market power. Manning (2003, 2011) and Ashenfelter, Farber and Ransom (2010) review most of the relevant papers. In the latter's view, they show that "the allocative problems associated with monopsonistic exploitation are far from trivial" (Ashenfelter, Farber and Ransom 2010, p. 209). The new creed has its critics too, such as Kuhn (2004) who finds Manning's (2003) evidence for his case for pervasive monopsony power lacking, especially in the long run.

We do not need to assess this controversy here however since what is of interest in the literature for the purpose of this paper is the theoretical framework that the terms of the debate take for granted. To our knowledge only Bellante (2007, p. 22) has weighed in the current debate to reject them, based on Rothbard's case against the perfect versus imperfect competition dichotomy. 


\section{The Nirvana FALlacy in MonOPSONY THEORY}

The whole point of debating by how much the elasticity of real world supply schedules deviates from perfection, as a proof for the existence and as a measure of monopsony power, must assume that the dichotomy between imperfect and perfect competition is valid in the first place. The distinction between a monopsony price and a competitive price for factors of production (or for any good), as well as the distinction between a monopoly price and a competitive price for their products, can be relevant only if competitive prices are within the realms of possibility. It must be possible for buyers to be price-takers, i.e. it must be possible for supply schedules that individual buyers face (and demand schedules that individual sellers face) to be perfectly elastic.

For Rothbard (1962, p. 721-22), perfectly elastic schedules could never be considered a possibility but for the habit of thinking of actions in terms of infinitely small steps, as a consequence of the perceived need to present economics in terms of mathematical models. For it is only in such a case that the decision of any buyer may be considered to be without any impact whatsoever on the total market demand and therefore on the market price. The problem is that what we are interested in actions- must run in terms of discrete steps ${ }^{2}$. The total quantity demanded of the factor on the market at any price is made of the quantities demanded by each individual buyer. Each one is a contributor and the individual decision to demand $\mathrm{x}$ instead of $\mathrm{y}$ units of a factor cannot but affect the total, and therefore the equilibrium price.

In order for the contribution of each to actually be negligible, total demand would have to be infinite. $\mathrm{n}+\mathrm{x}=\mathrm{n}$ only if $\mathrm{n}$ equals infinity. But there never can be such a thing as infinite demand. Demand must be limited by the scarcity of whatever one has to offer in exchange for the good under consideration. In other words, whereas no buyer (and no seller) can ever unilaterally decide what the price of a voluntary exchange will be, none can ever be a price-taker either. According to Rothbard, it follows that a supply schedule a buyer faces may or may not be very elastic, depending on the specifics of the case, but it can never be perfectly elastic (Rothbard 1962, p. 718).

2 After all, altering the state of the world, one way or another, presupposes that the individual actor uses means, combined in a definite quantitative relationship which he believes can help him achieve some ends. However, sizeless means can hardly produce anything but sizeless results (i.e. no alteration). Infinitesimal calculus may be convenient for mathematical modeling but action necessarily deals with concrete definite quantities. 
From Rothbard's analysis, one can deduce the following: Manning is correct in assuming that supply schedules are normally imperfectly elastic but not because of some market failure to conform to some realistic standard. Since the essential feature of perfect competition is impossible, "deviations" from it, including monopsony and other "imperfections", are unavoidable. Welfare comparisons based on this criterion imply a nirvana fallacy (Demsetz 1969): since such perfection is beyond anybody's reach, the standard of comparison is irrelevant ${ }^{3}$. It follows that in no case equilibrium can be characterized as a situation in which the marginal revenue product and the price of the factor of production are strictly equal. Instead the marginal revenue product -discounted by the "pure" (Rothbard 1962, pp. 367-451) or "originary" (Mises 1949, pp. 521-33) interest rate, in the Misesian framework- equals the marginal cost of hiring the factor in all equilibrium cases (Rothbard 1962, p. 695).

In addition, Rothbard (1962, p. 718) argues that as long as anyone is allowed to enter the market, profit can be arbitraged away, regardless of the degree of elasticity of a supply schedule at any

3 Applying this insight to Manning's approach, who explains less than perfect elasticity through search costs, one only needs to realize that there is no possible world in which they can disappear. There are search costs to be borne because no one is omniscient. If one argues that welfare losses result from this lack of omniscience, one might as well claim that having to pay any price at all for anything entails tremendous welfare losses as compared with the state of eternal bliss prevailing in the absence of scarcity. 
given time. ${ }^{4}$ As a result, there is no valid criterion to differentiate monopsony prices from competitive prices in the standard framework. If the idea of market power for a buyer can be saved then, it must be based on some other framework.

\section{Monopsony And Monopoly Theory without the Imperfect/Perfect COMPETITION}

\section{DICHOTOMY}

Noticeably, Mises and Rothbard's rejection of the imperfect vs perfect competition paradigm and the perfect elasticity benchmark did not lead them to reject monopoly price theory altogether. This is because they relied on the older view of monopoly prices based on the dichotomy between elastic and inelastic demand schedules above a "competitive" (Mises 1949, pp. 354-85) or "free market" price (Rothbard 1962, pp. 903-07). Focusing here on Rothbard's version, the theory states that if the market demand schedule for a good is inelastic above its free market price, threats of punishment for entering the field might alter the demand schedules addressed to the remaining firms from a greater than unitary elastic position to an inelastic position, so that they might restrict their sales,

\footnotetext{
${ }^{4}$ One might object the following: if supply schedules to individual buyers can under no circumstance be perfectly elastic, how is that compatible with full arbitrage? If the quantity supplied increases with price, the price of the factor is lower than its discounted marginal revenue product when the latter equals the marginal cost of hiring (even if, for simplicity's sake, we ignore discontinuities in the supply and the marginal revenue product schedules which could also bring about such an outcome). As a consequence, monetary profit is above zero. In order to have full arbitrage, the price of the factor, its discounted marginal revenue product, and the marginal cost of hiring, need to be equal, which in turn seems to require perfectly elastic supply schedules to individual buyers at the market-clearing price! It would appear then that Rothbard cannot have it both ways: either schedules cannot be perfectly elastic or full arbitrage can occur.
}

There is a way out of this conundrum, however. When Rothbard explains that perfect elasticity of a supply schedule to an individual buyer is impossible, he is assuming that the demand schedules of other buyers are given. This is why the decision of the individual buyer must affect the total quantity demanded on the market and the equilibrium price. If one drops this restrictive assumption, perfect elasticity need not require the assumption of negligible individual contributions to total market demand and full arbitrage is within the market participants' reach. All that is needed is to conceive of the supply schedules as incorporating the reactions of other buyers. For instance, total quantity demanded and the equilibrium price can remain unaffected when employer 1 hires less factors than what profit maximization would have required and employer 2 consequently hires more as he realizes that his competitor's choice can be taken advantage of. The gap left by the mistaken employer being filled by his competitor, total market demand and price remain the same and the supply schedule to employer 1 is perfectly elastic in the relevant area. Alternatively, if employer 1 correctly realizes that employer 2 stands ready to fill the gap, i.e. if he realizes that the supply schedule he faces is flat, he will not restrict his purchases in the first place. This solution is in line with Rothbard's take on the alleged problem of indeterminacy under oligopoly: "There is no reason why the demand curve to a firm cannot include expected reactions by other firms." (Rothbard 1962, p. 723-25)

The essence of Rothbard's case against the perfect/imperfect competition dichotomy stands, in that the idea of negligible individual contributions in perfect competition remains untenable, even if one can conceive of perfectly elastic supply and demand schedules on other grounds. There can be no price-taker, strictly speaking, no market participant without "market power". The neoclassical idea of the perfectly elastic supply schedules as a benchmark falls then, insofar as it is grounded on those ideas. 
thereby charging a monopoly price, to earn a higher income ${ }^{5}$. Now, one could have expected Mises and Rothbard to defend a monopsony price theory which does not rely on the perfect competition benchmark as well. But this was not the case, since the symmetry between imperfect competition in selling and in buying in standard theory (monopoly and monopsony prices as a consequence of less than perfectly elastic demand and supply schedules faced by sellers and buyers, respectively) is a consequence of the imperfect / perfect competition framework. ${ }^{6}$

Indeed, once one drops it and uses the elastic vs inelastic demand schedule criterion for monopoly prices, no equivalent criterion appears available on the other side of the monopoly coin, monopsony. Writes Mises (1949, p.380)

\begin{abstract}
Monopoly prices can emerge only from a monopoly of supply. A monopoly of demand does not bring about a market situation different from that under not monopolized demand. The monopolistic buyer -whether he is an individual or a group of individuals acting in concertcannot reap a specific gain corresponding to the monopoly gains of monopolistic sellers. If he restricts demand, he will buy at a lower price. But then the quantity bought will drop too.
\end{abstract}

This is certainly not meant to say that restrictions on buying do not make any difference in the pricing process, or that such restrictions cannot benefit the remaining buyers in any way ${ }^{7}$. Instead,

5 See Rothbard (1962, pp. 661-704) for the justification of his thesis than only aggressive violence or the threat thereof implies a market situation which is distinguishable from a "competitive" market environment.

6 Above we have argued that the possibility of perfectly elastic supply schedules to an individual buyer was compatible with the causal-realist or Misesian framework, as long as this elasticity would reflect some competitors' reactions (instead of being based on the idea that each individual's choice is negligible in its contribution to total demand, see footnote 4). In fact, we have suggested that the mere possibility of full arbitrage requires it. One might then wonder if this could not vindicate the standard theory, by recasting it in the Misesian framework: indeed, could one not argue that the standard model stands, now that we can realistically distinguish between various states of the market, with and without perfectly elastic schedules? The issue is the following, however: even if one could unambiguously observe supply schedules, why one's encounter with a less than perfectly elastic one could not merely be evidence that disequilibrium prevailed at that moment in time? A profit opportunity could have been missed. Since actors are not omniscient, error is an ever-present possibility (Rothbard 1962, p. 7) and full arbitrage does not automatically occur. As a consequence, factor prices may be above or below their discounted marginal value products and employers may incur losses or earn profits. But this has nothing to do with monopsony and those prices are no more or less "competitive" than the constellation resulting from full arbitrage. In the presence of a less than perfectly elastic schedule then, we would still miss a criterion to distinguish between a so-called monopsony price and a disequilibrium price due to mere error. Insofar as frictions in contemporary monopsony models are based on search costs, whose existence depends on the lack of perfect information, they must fail to identify such a criterion.

7 As Mises (1949; p. 380) adds: "In the same way in which governments restrict competition in order to improve the position of privileged sellers, they can also restrict competition for the benefit of privileged buyers. Again and again governments have put an embargo on the export of certain commodities. Thus by excluding foreign buyers they have aimed at lowering the domestic price. But such a lower price is not a counterpart of monopoly prices." 
the claim is that there is no analytical criterion allowing for a special category called "monopoly of demand price" or "monopsony price". This is because price and quantity vary in the same direction along a particular supply schedule, so that a lower price is always associated with lower expenses whereas price and quantity vary in the opposite direction along a demand schedule so that a higher price may be associated with higher or lower expenses depending on the elasticity of demand. The old monopoly price theory relying on that specific feature of a demand schedule, no equivalent exists when one discusses monopsony. In this sense there can be no such a thing as a monopsony price. Consequently, there can be no monopsony gain corresponding to the monopoly gain of monopolistic sellers. But the question remains then if a monopsony or oligopsony might take advantage of the exclusion of competitors to push prices downward in order to improve its lot, even if the resulting ratios may not properly be referred to as monopsony prices ${ }^{8}$.

Rothbard (1962, pp. 717-18), drawing on Mises (1949, pp. 593-95), would have none of that in the case of labor factors:

It is often alleged that the buyers of labor-the employers-have some sort of monopoly and earn a monopoly gain, and that therefore there is room for unions to raise wage rates without injuring other laborers. However, such a "monopsony" for the purchase of labor would have to encompass all the entrepreneurs in the society. If it did not, then labor, a nonspecific factor, could move into other firms and other industries.

In other words, only socialism with its unique employer could provide the sufficient conditions for lower wage rates ${ }^{9}$. And absent socialism, non-specificity of the factor would appear to be what protects its owners from the prospect of monopsonistic pressure, when government interventions hamper the bidding of employers. The implication seems to be then, for a market economy, that lower prices for the factors of production and the corresponding gains for the buyers are possible, but only when violent threats are made against would-be buyers of the factor -such as when licenses

8 To be sure, a monopsonist can take advantage of the exclusion of its competitors in the sense that any buyer, given a market supply schedule, is better off when the market demand schedule and equilibrium price are lower. But the gain here is not specific to his situation as a monopsonist. By the same token, the monopolist can benefit from the exclusion of competitors in the sense that any seller, given a market demand schedule, is better off when the market supply schedule is lower and the equilibrium price consequently higher. But this is not specific to his situation as a monopolist and occurs regardless of the elasticity of the demand schedule.

9 Even here, speaking of a monopsony price would be problematic since in socialism, there are no such things as market prices for factors of production anymore, be they competitive, monopolistic or monopsonistic. 
to buy are given to privileged buyers only- and when those factors of production, land factors or capital goods, are specific.

This is not explicitly stated and no attempt at a systematic analysis of pricing under such conditions is made. Mises and Rothbard both pay lip service to the limited possibility of lower prices under such monopoly of demand conditions under interventionism but only deny this to be possible for non specific factors without discussing other cases. Their followers on that question do the same (Block Barnett 2009, p. 80; Bellante 2007, p. 17). The following analysis both renders explicit what is implicit, in the case of specific factors and, drawing on Méra (2010), reveals that their conclusions regarding the case of non specific factors, including labor, is unwarranted, so that monopsonistic pressure on non specific factor prices can be a widespread phenomenon. But in order to better grasp this, one needs first to take a détour and establish in broad terms what relationship must exist between monopoly and monopsony, if any.

\section{MONOPOly AND MONOPSONY: TOWARD A THEORY OF MONOPOLY PRICE-GAP}

It will reveal useful below to introduce here a distinction between a "short run" and a "long run" analysis, or better stated, between an analysis of choice with already produced goods on the one hand and an analysis of choice regarding production decisions on the other, and to start with the first. It would seem to be all the more relevant given Mises's and Rothbard's way of approaching monopoly price theory. Indeed, even if they pay some attention to factor allocation in their analysis of the conditions for the emergence of monopoly prices, it is more as an afterthought (Méra 2015, pp. 127-31). Their analysis, as described above, tend to run in terms of already produced goods, ruling out production costs as a decisive consideration: the basic requirement for a monopoly price to emerge is that demand schedules to remaining sellers are made inelastic above the free market price (or "competitive" price, for Mises), allowing for the specific monopoly gain Mises is alluding to in the above quote. The "monopoly price" here is what Fetter $(1915, \mathrm{pp}$. 80-81) referred to as a "crude monopoly price", the qualifier emphasizing the lack of deliberations about production in this setting (while he referred to "monopoly price" in the context of production decision making).

If one contemplates monopsony through the same lens, the following picture emerges. Absent any production decision, the only choice one can be dealing with here, as far as a buyer is concerned, is 
the decision of a consumer. The first thing which needs to be stressed is that although it has been noticed in the literature that a monopsonist often is a monopolist, this is not the case here. The position of someone as a consumer-monopsonist is unrelated to any monopoly position she might have as a seller.

Second, restricting the quantity she will buy does not bring about any gain, even if a lower price can thereby be paid. No rationale comes into play here which would explain why the buyer could be interested in restricting his exchanges in a similar way to what one envisages in monopoly price theory. If that was advantageous to her, her demand schedule would have been lower in the first place. In perhaps a stronger sense than Mises meant then in the above quote, "a monopoly of demand does not bring about a market situation different from that under not monopolized demand" when one speaks of a demand for consumption goods. There is no symmetry beyond the fact that competitors are excluded in both cases: monopoly can bring about monopoly prices but no monopsony price emerges from such a monopsony situation. ${ }^{10}$

So far Mises's case against the symmetric impact of monopoly and monopsony is unobjectionable, but does it imply that there can never be such a thing as lower factor prices specifically resulting from a monopsonist's choices? Does this mean that most economists have been on the wrong track in endorsing one variant or another of monopsony theory, including Mises's predecessor as the master of Austrian price theory, Eugen von Böhm-Bawerk? Is there a fatal flaw in the latter's discussion of "wage determination under employer's monopoly" for instance, where, although he does not discuss an economy-wide monopoly but a cartel of employers in an industry, he nevertheless states that (Böhm-Bawerk 1962, p. 165):

The rate of wages would be fixed according to the general formula applying to a purely selfish monopoly, already mentioned before in another connection: they would be fixed at that point which promises the largest returns, after a careful consideration of all circumstances, and with due regard to the inevitable fact that with changing prices, the amount of goods to be disposed of profitably will change, only that in the case of a buyers' monopoly the results are exactly opposite to that of a sellers' monopoly.

10 Again, it is true that the equilibrium price will be lower as a consequence of the exclusion of competing would-be buyers. But the gain involved is not specifically a monopsonistic gain. In fact, far from aiding in somehow restricting demand, a simple supply and demand analysis shows that the monopsonist here buys higher quantities than he would have bought if his competitors were not excluded. 
Or stated concretely: the lower is the wage rate fixed by the monopolist, the smaller will be the number of workers available, and from a correspondingly smaller number of workers will the entrepreneurs be able to collect that increased return which might accrue from pushing the wage scale down below the value of the product of the marginal laborer [...] in fact, this value might even increase through a reduction in the output, which would cause a rise in the price of the finished goods. ${ }^{11}$

The situation here is different from the one the consumer-monopsonist finds herself in however, since Böhm-Bawerk deals with capitalists-entrepreneurs hiring factors of production. This is the realm of production decisions, more specifically the production decisions of those who invest their money in a productive process. In their capacity of capitalists-entrepreneurs, they both act as buyers and sellers, sequentially, with or without physical transformation of what has been bought in the meantime, and they buy in order to sell and earn a net income based on a hoped-for price differential. Now this has profound implications for the issue at hand, which neither Böhm-Bawerk nor Mises and Rothbard appear to have completely drawn: monopsony implies a different market situation when buyers are producers, although the corresponding gain might not be specific to the buyers' position as monopsonists only.

Indeed, the first implication which needs to be stressed here is that, whether some threat of infringing upon the property rights of some would-be capitalists-entrepreneurs is made in their capacity of sellers (granting a monopoly privilege to other capitalists-entrepreneurs) or in their capacity of buyers (granting a monopsony privilege), or both, the restriction on one is a de facto restriction on the other (Wieser 1927, p. 219; Méra 2010, p. 55). This is because buying and selling are part of the same production plan, so if someone is barred from entering the market as a

11 To avoid any misunderstanding, at the time Böhm-Bawerk was writing, the word "monopsony" was not in use yet. Economists were only speaking of a "monopoly of demand", hence the expression "monopolist" here, not to be confused with the monopolist as a seller. 
producer-seller of a product, he will not compete on the market for the required factors of production (at least, not for that particular use) and vice versa. ${ }^{12}$

If it has often been noticed that a monopoly was a monopsony or a monopsony was a monopoly, this has rarely been considered a necessity. And it is true that, with an exclusive grant of monopoly privilege on the sale of some good, one may be its sole seller and one among many buyers of its non specific factors of production. However, even in this case competition is hampered on the factors' markets since no competitor is allowed to hire them for the production of the monopolized good. With an exclusive grant of monopsony privilege, one may be the sole buyer of a factor of production and one among many sellers of some good it helps producing, provided this factor is not indispensable to its production. But even in this case competition is hampered in the product market since competitors are not allowed to produce it with this factor.

The only way the capitalist's positions as a buyer and as a seller could be considered as independent is by introducing the perfect competition hypothesis in one market or the other. Then one could claim that the exclusion of some competitors from the perfectly competitive market has a negligible impact on the price (as long as it still has many participants competing, that is). A capitalist could then be a price taker in one market and a price maker in the other. But we already ruled out perfect competition as an irrelevant point of reference. Outside perfect competition then, the forced exclusion of some competitors will make a difference, albeit very small in the above case. No one's position in the product market is independent from one's position in the factors' markets. The impact of hampering competition in one market must reverberate throughout the others. In the large sense of being shielded from the competition of some other capitalists, a privileged capitalist is both a monopolist and a monopsonist.

Second, cast in that light, it immediately seems plausible that monopsony-monopoly is a market situation in which prices are affected in both the product markets and the factors markets, or at least

12 One could then wonder if it makes any sense to speak of "monopoly" and "monopsony" instead of "monopoly" for the whole setting. However, in the structure of production, not everyone can be both a buyer and a seller in its capacity as a producer, not everyone can be a capitalist. Some will have to be sellers of original factors' services since production processes must use some original factors of production (land and labor factors). As a consequence, it still makes sense to maintain the distinction between buyers' monopolies and sellers' monopolies because some people can only be granted a monopoly of supply. The symmetry here is with the situation of a consumermonopsonist who cannot be a monopolist. They have one thing in common, which is that they cannot be both monopolists and monopsonists, while capitalists are both insofar as at least some of their would-be competitors are forcefully excluded from the relevant markets. 
the product markets and the divisible factors markets. All that seems really necessary here for such an outcome to emerge is that monopoly-monopsony hampers the arbitrage process otherwise occurring across the whole social structure of production in all its dimensions, in such a way that the price-gap between products and factors cannot be reduced to the height determined by time preferences $^{13}$.

Before examining in more details the required conditions for such a result, at this stage let us emphasize that this is simply another aspect of the process described by Böhm-Bawerk in the above quote, and that this contradicts Mises and Rothbard's idea that no downward pressure on wages exerted by a cartel of employers can ever succeed in establishing a permanently lower wage rate for some workers. On the other hand, what Böhm-Bawerk hints at, when realizing that product prices will rise when capitalists-monopsonists "fix" a lower wage rate, but seems to miss nevertheless, is the idea that monopoly and monopsony go hand in hand for capitalists. As a consequence he sees both situations as symmetric but unnecessarily intertwined and suggest then that there can be a specific gain for a buyer's monopoly and a specific gain for a seller's monopoly. But if monopolistic grants of privilege to capitalists grant both kinds of monopoly to them as sellers of their products and as buyers of the required factors, no matter how the restriction was nominally introduced, if monopoly and monopsony are two sides of the same coin, then there is no specific gain to each. There is no specific gain for the monopsonist corresponding to the gain of a monopolist in the same sense than there is no separate interest revenue for a capitalist as a buyer of factors' services and as a seller of their products. The capitalist-monopolist benefits from a specific monopoly price-gap accounting for a specific gain.

Now, even if speaking of a gain associated to the capitalist as a buyer only is problematic, since the alterations of factor and product prices accounting for it are certainly not independent, a special emphasis on factor prices is required when reassessing monopsony theory and its features. In order to explain under what conditions the monopoly price-gap can arise and the contribution of lower factor prices to such an outcome, it is convenient to start with the simpler case involving factors of production specific to their industry.

13 Or whatever cause actually results in a "normal" price-gap. See Mises (1949, pp. 521-33) for the view that such an "originary" interest rate is determined by time preferences. 


\section{The Monopoly Price-Gap with Specific Factors of Production}

Under (general) equilibrium in the free market, i.e. when all expectations errors have been avoided and no privilege in buying or selling exists (free competition), all profits and losses have been arbitraged away so that the remaining gap between the average expense on factors of production and the price of the product -or between the marginal value product of any factor and the marginal cost of hiring it- remunerates the capitalist qua capitalist ${ }^{14}$. For any remaining firm at this point, any attempt to increase net income would be self defeating as long as preferences, resources and all the determinants of this equilibrium position remain the same. Expansion would be such that gross income would fall while expenses would rise or, that gross income would rise at a slower pace than expenses. On the other hand, if a firm would try to increase net revenue by buying and selling less, it would fail because its income would fall at a higher pace than its expenses. Gross income would fall and not rise, because the demand schedule to the firm for its product must be elastic above the equilibrium price (otherwise the initial situation would not be properly characterized as general equilibrium) and it would fall at a higher pace than expenses (for the same reason). In other words, the supply schedules of the factors of production and the demand schedule that each firm faces for its product must be elastic enough in the voisinage of their equilibrium prices that no other choice would bring about a higher net income for the firm owners ${ }^{15}$.

Therefore a grant of monopoly-monopsony privilege can increase the gap if and insofar as the forced exclusion of competitors decreases the elasticity of the demand schedule for the product and/ or the elasticity of the supply schedules of the factors in the relevant ranges (above the free market equilibrium price of the product and below the free market equilibrium prices of the factors), so that the net incomes of the remaining firms are maximized through contraction in this branch (compared to the free market level of activity). In this market situation, a monopoly-price gap emerges and the corresponding monopoly gain under the new equilibrium position cannot be arbitraged away.

Let us assume that a grant of monopolistic privilege has been conferred upon some firms in the

14 Error being an ever present possibility in the realm of human action, there is no reason that equilibrium, especially general equilibrium, must occur. The assumption is made here only as a way to analytically disentangle various sources of discrepancies in the rates of return one can observe in an actual market economy.

15 If we conceive of those schedules as incorporating the competitors' reactions, they will be perfectly elastic (see footnote 4). This must be true for the demand schedules for the product of each firm. Otherwise, the product price would be higher than the marginal revenue product when the latter equals marginal cost (plus the originary interest differential) and there would still be room for further arbitrage. 
chocolate industry (as sellers of chocolate) ${ }^{16}$. The more exclusive the grant is, the less elastic the demand schedule to each remaining firm becomes, the more drastic the contraction and the higher the new product price will be. If only one seller is authorized, it faces the whole market demand schedule, which is necessarily less elastic than the demand schedules all the competing firms would have faced under less restrictive conditions. As a consequence, the net income-maximizing quantities of output and of factors hired are bound to be lower than they would otherwise be.

Four remarks are in order at this stage. First, and directly relevant to our central concern here about monopsony theory, the monopoly price-gap is partially accounted for by lower factor prices, if it is true, as explained above, that there can be no such thing as a perfectly elastic factor supply schedule. Clearly, lower production requires less units of at least one divisible factor, a market situation under which no upward pressure on its price can be felt (Méra 2010, pp. 57-59), and contraction can then be implemented by "moving along" the supply schedule to a position where the price is lower (with lower quantities bringing about a higher price for the product). ${ }^{17}$

Second, how low depends on the reservation demand of the factor owners. With a specific factor, the alternative only consists in being employed by another of the remaining employers if any remains or, in being unemployed. If the monopoly grant was exclusive to one firm, this firm is the sole buyer of the services of the factor. It faces the market supply schedule of the factor, which must be less elastic than any supply schedule any one firm faces under less restrictive conditions. The more exclusive the grant is, the more drastic the contraction and the fall in the specific factor prices are. What this means here is that it is not simply that prices must fall because there is never such a thing as a perfectly elastic supply schedule that buyers face. It is that hampering competition results in those supply schedules to each remaining buyer becoming less elastic, which must then account for a part of the monopoly price-gap. This must be the case if it is true as explained above, that the situation of capitalist as buyers is not independent from their positions as sellers, so that hampering

16 The assumption is that one or several sellers have been given a license to sell chocolate, so that no one else is allowed to. This is an explicit monopoly grant. However, it should be clear that any other regulation which, in effect, drives competitors out of the market is not fundamentally different.

17 Here we cannot simply claim that if one takes the competitors' reactions into account, the schedule can be perfectly elastic at the initial price so that the price could not be lowered (see footnote 4), for the possibility of reacting in a way which renders the schedule perfectly elastic (full arbitrage) is precisely what the monopolistic grants restricts. 
competition in the chocolate market de facto hampers competition in its specific factor markets. ${ }^{18}$

Third, this does not mean that a grant of privilege makes no difference, whether it is a monopoly grant on the sale of chocolate or a monopsony grant on the purchase of one or several of its specific factors. In the second case, it could be that other ways to produce the same chocolate product are known, which do not require the use of this specific factor. One would then expect the elasticity of the demand schedule for chocolate faced by remaining sellers to be relatively less impacted than the elasticity of the supply schedules of this factor that they face as buyers. As a consequence, the monopoly price-gap would arise more as a consequence of a fall in the specific factors's prices than as a consequence of a rise in the product price, while both would nevertheless occur.

Fourth, to the extent that a lowered factor price is related to a change in the elasticity of the supply schedules faced by the remaining buyers, one may refer to the resulting price as a "monopsony price". Recall that Mises had ruled out that the concept of a monopsony price or "monopoly of demand" price makes sense because no equivalent to the inelasticity of demand criterion for monopoly prices existed in monopsony. However, this inelasticity criterion turns out not to be decisive anymore once one shifts focus from "crude monopoly price" theory towards the analysis of the requirements for the emergence of a mere "monopoly price" in the context of production decisions. Indeed, as Méra (2015, pp. 130-31) argues, Mises (1998, p. 7) implicitly admitted this when he allowed himself to discuss the emergence of monopoly prices in relation to production expenses, by devising an instance of monopoly price reached through a move along an elastic demand schedule (with the move being profit-enhancing since the example was devised in such a way that the fall in expenses was higher than the fall in gross income). And as Rothbard (1970, p. 44) claimed, contradicting his previous presentations of the theory, the relevant circumstance for a monopoly price to arise is that a demand schedule to a firm is made "sufficiently less elastic" through the forced exclusion of competitors, not necessarily that it is made inelastic, after all. If it is legitimate to refer to such an outcome as a monopoly price, then it is certainly legitimate to refer to its counterpart in the factors markets and its outcome as monopsony prices ${ }^{19}$.

18 Incidentally, this means that the standard distinction between the case in which labor allocation and pricing is affected by monopsony (Borjas 2013, p. 187-94) and the case in which it is affected by monopoly in the market for the product (Borjas 2013, pp. 194-97) does not hold anymore in our framework.

19 It follows that, for the analysis of production decisions, the Mises-Rothbard-inspired theory of monopoly price-gap, with monopoly and monopsony prices as its symmetric components, is actually more similar to the mainstream one than what Mises's and Rothbard's explicit discussions of monopoly prices and monopsony would have suggested, with the important difference that it has no room for a perfect competition benchmark. 
Semantics aside, the most important result here is that a monopoly price-gap can emerge with higher product prices and lower specific factor prices, specifically as a result of the monopolists' choice to contract their activity in order to take advantage of demand schedules for the products and supply schedules for their factors made less elastic through the threats of fines, taxes, imprisonment and other coercive methods.

\section{The Monopoly Price-GaP: Non-Specific Factors AND the LAW OF Costs}

What difference non specific factors make? Is it true that non-specificity shields them, and especially labor factors among them, from monopsonistic pressure? Or, recasted in the framework of the monopoly price-gap theory above, could it be that only increases of the product prices (as well as decreases of the specific factor prices) account for the price-gap and monopoly gain?

First, in regard to labor, the sense in which Rothbard speaks of it as non-specific, when he claims that only an all-encompassing monopsony could extract a gain from it, does not appear to be the strict one. He must allude to "labor-in-general" (Rothbard 1962, pp. 572-75), as a class of factors. Otherwise the universal monopsony clause could hardly be required. Strictly speaking, a nonspecific factor performs a task which can be used in several production processes (Rothbard 1962, p. 39) but is nevertheless "homogeneous in its supply" (Rothbard 1962, p. 562). This is certainly true of many tasks that laborers are able to perform. But labor-in-general is non-specific in the larger sense that each person is able to perform various labor tasks. It would be more accurate to say then, if one sticks to the strict definition, that a person normally can embody several labor factors and that she can switch from being a supplier of one to a supplier of another. The reason it is important to keep this in mind is that there is going to be a different marginal revenue product schedule for each task. And the next most remunerative task that an employee will be able to perform may pay far less than the ongoing one. Furthermore, this particular factor they embody, may be specific to the process they participate in. As a consequence, privileged employers (monopolists-monopsonists) may be in a position to pay a lower than free market wage rate without such workers fleeing en masse to another field, although the lower limit below which the latter 
would quit is higher than if they could not perform other labor tasks. ${ }^{20}$

Now what about a genuinely non-specific factor, be it a labor factor, a land factor or a capital good? Rothbard claims, following Mises, that the non-specific factor would just go elsewhere if the employer attempts to push its price below the free market level. One problem here is that Rothbard's point proves too much. If it really followed from the non-specificity of a factor that a monopsony could not lower factor prices, would it not follow too from the marketability of money that no monopoly price of the sort Rothbard envisages can emerge from a monopoly of supply? After all, one could say that the buyers' money "can move elsewhere" when the monopolist tries to charge a monopoly price, especially since money is the non-specific asset par excellence, by definition. But the theory of monopoly price, as understood by Rothbard and others, implies that such non-specificity does not prevent monopoly pricing.

This suggests that there is something wrong about Rothbard's view but does not pinpoint what the issue is exactly. The essential weakness in the thesis of the necessity of socialism to lower nonspecific factor prices should be clear, however. For this thesis begs a question: for what price could non-specific factors move into other firms and industries under partial monopsony? The claim suggests that the prices the factor owners can charge elsewhere are a given, an "independent variable" which has nothing to do with the pattern of monopolistic action under examination. And yet the well-known insights about the price relationship between substitute goods (Rothbard 1962, pp. 280-88), combined with the distinctively Austrian "law of costs" imply that this is not the case.

Böhm-Bawerk (1930, pp. 223-34) had developed the view of costs, in the sense of money expenses, as ultimately determined by consumers' preferences so that the determination of relative prices has to be entirely driven by consumers in the market. In the absence of obstacles, arbitrage would align the prices of the products with their costs throughout the economy: that was the common knowledge shared by classical and pre-classical economists. But where are the costs coming from? For Böhm-Bawerk and the Austrians after him, there was to be no such thing as a "natural price" derived from a somewhat exogenous cost of production. Capitalists who want to keep operations going in whatever industry have to advance payment to factor owners at such a level of price that they would not go elsewhere. The price the factor owners can obtain elsewhere is the bid of other

20 In this respect, one would then expect that the possibility of lowered wages under monopsony-monopoly pressure would mostly concern very specific, highly qualified jobs, as Block Barnett (2009, p. 73-74) claim. 
capitalists. And the most that each capitalist can profitably pay in a particular stage of a process is determined by what the capitalists at the next stage will be ready to pay, which is in turn determined ultimately by what consumers will be ready to pay for the final product of these factors in this branch. Capitalists everywhere compete for the use of these factors and the whole arbitrage process then determines costs of production as imputed backward from consumption goods prices, not the other way round. Hence the height of the bids for factors of production anywhere at the beginning of a stage of production depends on the expected income from the sale of their products received at the end of the stage, which is ultimately determined by consumer choices.

What is missing then when Rothbard tells us that non-specific factors can just go elsewhere when a monopsonist attempts to bid down their price is the following: since a grant of monopolymonopsony may distort the pattern of spending on various products ${ }^{21}$ beyond the one produced by the monopolist, the upper limit on the capitalists' bids for the factors of production "elsewhere" may be a different price than it would be absent the grant.

Indeed, what happens on the side of the buyers of a product when a monopolist produces and sells less than he could have if he had been happy to earn a "normal" income only? Let us assume first that the demand schedule above the free market price is inelastic, for even though this is not a necessary condition for such a decision to pay off, it certainly helps. In such a case, the pattern of spending by its clients is altered in such a way that they are going to spend more on the product they have to pay a monopoly price for and less on other products than they would have otherwise. This means that their demand schedules for those other goods are lower. Therefore, their prices tend to be lower and capitalists-entrepreneurs had less reasons to invest there than they would have had otherwise. In other words, the marginal revenue product schedules of the factors employed there were lower than otherwise. Now, if a factor used in the production of the product charged a monopoly price is also used in one or several of those sectors, its lower marginal revenue product schedules there affected its reservation demand here, in the first process (Méra 2010, pp. 59-64). What he can earn "elsewhere" can be negatively impacted by the monopolistic pattern of action occurring here, via the spending shift of the final buyers of its products.

Insofar as there exists a tendency for those factors to command a lower price elsewhere because of

21 As Rothbard (1962, p. 905) puts it, "the consumers are only fully responsible for their demand curve on the free market; and only this demand curve can be fully treated as an expression of their voluntary choice." 
those shifts, their reservation demand here is impacted. Their supply schedule here becomes even less elastic below the free market price, with more room for a monopolistic-monopsonistic contraction and the establishment of a monopsony price than otherwise, reflecting the formation of a larger phenomenon, a monopoly price-gap. The fact that under monopoly-monopsony here, they can earn less than they otherwise could here and elsewhere are two sides of the same pattern of action originating in the monopolistic grant. And the less specific such a factor is, the higher the likelihood he will be in use in a branch where its marginal revenue product schedule must be lower because of the aforementioned shifts. This is why non-specificity of a factor does not automatically shield its owners from the adverse effect of monopolistic-monopsonistic pressure. Depending on the direction of the spending shifts on products, it can on the contrary expose the owners to that effect.

On the other hand, what if the demand schedule for the good a monopolist produces remains elastic above the free market price? A monopoly price then results in lower spending on the product (the monopolist, if successful, will have correctly anticipated that this lower income is more than compensated by lower expenses). This means that the demand schedules for other goods are higher. Therefore, their prices tend to be higher and capitalists-entrepreneurs were justified in investing more there than they would have had otherwise, which implies the marginal revenue product schedules of the factors used there is higher. If a factor used in the production of the product charged a monopoly price is also used in some or all of those sectors, its higher marginal revenue product schedules there affected its reservation demand here. This is a factor in the increase of the elasticity of its supply schedule to the monopsonist-monopolist, although the exclusion of competitors inherent in this monopsony position has the opposite effect.

What this means is that there is less room for a monopoly price-gap in such a case, although one cannot rule out the possibility since the elasticity of the demand schedule for the monopolized product could still have decreased relative to the elasticity of the supply schedules of its factors of production in the relevant ranges. And there is even less room for the establishment of a monopsony price for the factor (a price which would be lower as a consequence of employers taking advantage of an absolute decrease of the elasticity of its supply schedule), although it remains possible. Here non-specificity is a mitigator or even a shield, but whether it is one, whether it is neutral or whether it increases monopolistic-monopsonistic pressure on the factors' prices depends on the direction of 
the shifts in spending on the products and on what goods those factors help produce. ${ }^{22}$

\section{CONCLUSION}

The possibility of lower non-specific factor prices as a consequence of grants of monopolistic privileges, deduced from Böhm-Bawerk's law of costs and the law of substitutes, suggests that we are presented here with an anomaly in the history of economic thought, that this paper was intended to identify and correct. The anomaly is that it is the authors who had not followed Böhm-Bawerk who insisted there existed significant room for monopsony distortions in the economy while the authors who had placed him on a piedestal tend to dismiss concerns about monopsony, even when it is conceived as a manifestation of interventionism. This is an anomaly insofar as the first tended to come from the partial equilibrium Marshallian tradition (Robinson), which naturally lead to take factor prices outside the branch one focuses on as given, while the second had endorsed an insight that might have lead them to think of those factor prices elsewhere as dependent on what is going on inside the branch. In other words, taking Böhm-Bawerk's law of costs seriously could have lead to think that there is more room for monopsony distortions in a market economy than what a Marshallian approach suggests. And yet, the opposite occurred, by and large.

If monopsony theorists, and especially the new wave of scholars among them, have been able to push monopsony theory as an empirically relevant piece of theorizing, it is because they went on a completely different track of course. Pure and perfect competition was given a benchmark status for welfare comparisons so that any deviation from it originating from any source could be considered as an issue in need of corrective action. A less than perfectly elastic supply schedule of a factor of production, for instance, could be taken to be a manifestation of its employer's market power and a sign of inefficiency in resource allocation.

22 In this paper I essentially focus on what factor prices and production in a branch where a monopoly-monopsony grant exists to explain how a monopoly price gap can arise. Other industries are dealt with only insofar as the grant indirectly affects the marginal revenue product schedules of the very same factors there, leaving more or less room for a monopoly price gap (and therefore a monopsony price) in the first. However, other indirect consequences in the pricing process are to be expected and felt virtually anywhere in the economy. For a more complete analysis, see Méra (2010): in short, grants of monopoly-monopsony privileges to capitalists imply a prevailing tendency for lower land and labor prices and aggregate income than under free competition, even though some of them may command higher prices, the overall distribution of incomes being altered to the disadvantage of those classes of factors. In addition, the overall output is reduced insofar as some units of those factors leave production altogether in the face of declining prices for their services while the allocation of the remaining units is distorted to the detriment of the bulk of consumers. 
What has been argued here is that this way of conceiving of the issue is a dead end, in that it compares real world situations with an impossible ideal, so that mainstream monopsony theory, old and new, lacks a realistic criterion to distinguish between monopsony and its absence, monopsony prices and competitive prices. This is the application to monopsony of the fundamental Austrian criticism of the imperfect vs perfect competition paradigm, which is at the heart of mainstream monopsony theories. On the other hand, this paper has challenged the Austrian view that any monopsony theory should therefore be considered as of little empirical relevance at best and as an absurd piece of theorizing at worst.

On the contrary, once one endorses a causal-realist outlook in the Mises-Rothbard tradition, the view that human action occurs in discrete steps and that the supply schedules of factors of production can be made less elastic as a result of coercion, leads to an Austrian theory of a monopoly price-gap, with monopoly and monopsony prices as two features of the same phenomenon. A monopoly price-gap and a corresponding monopoly gain can emerge when the everyday arbitrage activities of capitalist-entrepreneurs throughout society's structure of production are hampered in such a way that the demand schedules for products and the supply schedules of their factors of production are made less elastic as a consequence of coercion.

The possibilities of such distortions are more widespread in a market economy than what Mises and Rothbard's writings on monopoly price theory suggest is possible, for two reasons. First, the requirement they put forward for the formation of a monopoly price -demand schedules for products made inelastic- is valid only in the context of decisions over an already produced stock of a good. In the realm of production decisions, there is no need for the demand schedules to become inelastic for contraction to pay. This is because maximizing gross income is not the relevant consideration. Expenses are compared with gross incomes, so that an expected falling gross income is an insufficient reason not to contract activity. Contraction and its outcome, lower factor prices and higher product prices, can therefore be a more widespread phenomenon than what the inelasticity of demand-based theory suggests. Second, non-specificity of the factors of production does not necessarily protect their owners from monopolistic-monopsonistic pressure since what they can earn outside of the monopolized branch of industry can be negatively affected as an indirect consequence of that very same grant. 
Finally, if coercion-induced changes in the elasticity of the demand schedules for products and the supply schedules for their factors are the decisive requirements for monopsony prices and a monopoly price-gap to emerge, it immediately follows that the removal of those grants is what allows wage rates and the marginal revenue product of labor factors to be as close as humanly possible at any given time. A thorough analysis of minimum wage legislations goes beyond the scope of this paper, but while such price controls can conceivably mitigate the impact of monopolymonopsony on factor prices, if they are not set above and remain below (prone to change) marketclearing prices, their lack of flexibility and adaptability to various factor markets and situational changes render them rather inadequate, as compared with abolitionism.

\section{REFERENCES}

Ashenfelter, Orley C. Henry Farber, and Michael R Ransom. 2010. "Labor Market Monopsony”. Journal of Labor Economics Vol 28, No 2. pp. 203-210.

Bellante, Don. 2007. "The Non Sequitur in the Revival of Monopsony Theory.” The Quarterly Journal of Austrian Economics Vol. 10, No. 2, pp. 15-24.

Blair, Roger D., and Jeffrey L. Harrison. 2010. Monopsony in Law and Economics. Cambridge University Press.

Block, Walter E., and William Barnett. 2009. "Monopsony Theory.” American Review of Political Economy Vol. 7, Nos. 1/2, pp. 67-109.

Boal, William M., and Michael R Ransom. 1997. "Monopsony in the Labor Market”. Journal of Economic Literature Vol. 35, No. 1, pp. 86-112.

Böhm-Bawerk, Eugen von. 1962. “Control of Economic Law?”. Shorter Classics of Eugen von Böhm-Bawerk, Vol. 1, pp. 139-99. South Holland: Libertarian Press, Inc.

- 1930. The Positive Theory of Capital. William Smart trans. New York: G. E. Stechert \& Co.

Borjas, George. 2013. Labor Economics. Sixth Edition. New York: McGraw-Hill Education.

Clark, John B. 1915. Essential of Economic Theory. New York: The MacMillan Company.

Burdett, Kenneth, and Dale T. Mortensen. 1998. "Wage Differentials, Employer Size, and Unemployment.” International Economic Review Vol. 39, No. 2, pp. 257-273. 
Council of Economic Advisers. 2016. "Labor Market Monopsony: Trends, Consequences, and Policy Responses”. White House Issue Brief, October 2016. https:// obamawhitehouse.archives.gov/sites/default/files/page/files/ 20161025_monopsony_labor_mrkt_cea.pdf

Davenport, Herbert J., 1913. The Economics of Enterprise. New York: The Macmillan Company. Demsetz, Harold. 1969. "Information and Efficiency: Another Viewpoint" The Journal of Law \& Economics Vol. 12, No. 1, pp. 1-22.

Fetter, Frank A., 1915. Economic Principles. New York: The Century Co.

Friedman, Milton. 1976. Price Theory. Chicago: Aldine Publishing Company.

Irwin, Neil. 2016. “A New Movement in Liberal Economics That Could Shape Hillary Clinton’s Agenda". The New York Times, November 4. http://www.nytimes.com/2016/11/06/upshot/ monopsony-liberal-economics-policy-hillary-clintons-agenda.html?smid=fb-share\&_r=1.

Klein, Peter G., 2008. “The Mundane Economics of the Austrian School”. The Quarterly Journal of Austrian Economics Vol. 11, No. 3 \& 4, pp. 165-187.

Kuhn, Peter. 2004. "Is Monopsony the Right Way to Model Labor Markets? A Review of Alan Manning's Monopsony in Motion.” International Journal of the Economics of Business Vol. 11, No. 3, pp. 369-78.

Machlup, Fritz. 1952. The Political Economy of Monopoly: Business, Labor, and Government Policies. Baltimore: The John Hopkins Press.

Manning, Alan. 2011. "Imperfect Competition in the Labor Market". Handbook of Labor Economics Vol. 4B. Eds David Card and Orley Ashenfelter, pp. 973-1041. Amsterdam: Elsevier.

.2008. "Monopsony." The New Palgrave Dictionary of Economics, Second Edition. Eds.

Steven N. Durlauf and Lawrence E. Blume. Palgrave Macmillan. <http://

www.dictionaryofeconomics.com/article?id=pde2008_M000373> doi:

$10.1057 / 9780230226203.1136$

-2006. "A Generalised Model of Monopsony”. The Economic Journal Vol. 116, No. 508, pp. 84-100.

—. 2003. Monopsony in Motion: Imperfect Competition in Labor Markets. Princeton University Press.

Méra, Xavier. 2015. “A Note on the Limits to Monopoly Pricing.” The Next Generation of Austrian Economics: Essays in Honor of Joseph T. Salerno, pp. 123-36. Eds. Per Bylund and David Howden. Auburn, Al.: Mises Institute. 
_. 2010. "Factor Prices under Monopoly" The Quarterly Journal of Austrian Economics Vol. 13, No. 1, pp. 48-70.

Mises, Ludwig von. 1998. "Monopoly Prices.” The Quarterly Journal of Austrian Economics Vol. 1, No. 2, pp. 1-28.

-1949. Human Action: A Treatise on Economics. The Scholar' Edition. Auburn, Al.: Mises Institute, 1998

Robinson, Joan. 1933. The Economics of Imperfect Competition, Second Edition. MacMillan St Martin's Press, 1969.

Rothbard, Murray N. 1962. Man, Economy, and State: A Treatise on Economic Principles. Auburn, Ala.: Mises Institute, 1993.

1970. Power and Market: Government and the Economy. Auburn, Ala.: Mises Institute, 2006.

Wieser, Friedrich von. 1927. Social Economics. A. Ford Hinrichs, trans. New York: Adelphi Company. 